\title{
Arrhythmia and structural abnormalities of the fetal heart
}

\author{
P A STEWART, H M TONGE, J W WLADIMIROFF
}

From the Department of Clinical Genetics and the Department of Obstetrics and Gynaecology, Academic Hospital Rotterdam-Dijkzigt, Erasmus University Rotterdam, Rotterdam, The Netherlands

SUMMARY Thirty fetuses with cardiac arrythmias were referred for ultrasonography. This included cross sectional and $M$ mode echocardiography and pulsed Doppler analysis of the fetal heart. Three types of arrhythmias were observed: ectopic beats, tachyarrhythmias, and bradycardia. Ectopic beats were associated with cardiac structural abnormalities in two cases, resulting in fetal death in one. Tachycardia was not associated with structural defect, but death from cardiac failure occurred in one patient. Transplacental treatment for tachyarrhythmia was not successful in our experience. In the group with bradycardia four cases had congenital cardiac abnormalities and the mortality rate was $50 \%$.

When a fetal cardiac arrhythmia has been established careful structural and rhythm analysis is of vital importance in facilitating prognosis, planning of time and mode of delivery, and monitoring of transplacental treatment where indicated.

Increasing attention is being paid to the prenatal diagnosis of cardiac structural defects by means of real time cross sectional scanners ${ }^{1-4}$ and the value of $M$ mode recordings in the analysis of cardiac arrhythmias. ${ }^{5-8}$ This study emphasises the importance of careful structural and rhythm analysis of the fetal heart when a cardiac arrhythmia has been established.

\section{Patients and methods}

Between January 1982 and April 198330 patients with fetal cardiac arrhythmias were referred to our ultrasound unit. The gestational age ranged from 21 to 41 weeks (median 31.9 weeks), maternal parity from 1 to 6 (median 2), and maternal age from 20 to 36 years (median 27.4 years). There was no history of congenital heart disease.

After initial detection of fetal heart rate or rhythm disturbance by monoaural stethoscope or continuous Doppler equipment a detailed ultrasound examination was carried out. This examination included overall assessment of fetal size and structure, placental location, and amount of amniotic fluid; a search for cardiac structural defects and possible signs of cardiac compromise such as pericardial effusion, increase in size of the right heart, and ascites.
For these purposes a phased array or mechanical sector scanner with a $3.5 \mathrm{mHz}$ or $5 \mathrm{mHz}$ transducer was used (Hewlett Packard 77020A Ultrasound Imaging System or Diasonics Cardio Vue 100). M mode analysis (Hewlett Packard 77020 A or Diasonics Cardio Vue 100) of atrial and ventricular rate and rhythm, analysis of the supra-abdominal fetal electrocardiogram (Corometrics Medical Systems Inc 112 Fetal Monitor), and pulsed Doppler assessment of blood flow in the fetal descending aorta, ${ }^{9}$ reflecting cardiac contraction force were performed.

\section{Results}

Tables 1, 2, and 3 give the findings on ultrasound and on clinical examination and the fetal outcome. Three types of arrhythmia were observed: ectopic beats $(n=17)$; tachycardia ( $>180$ beats $/ \mathrm{min}, \mathrm{n}=5)$, and bradycardia $(<100$ beats/min, $n=8)$. The ectopic beats were usually supraventricular and disappeared before or shortly after birth. In one case ventricular extrasystoles were seen. In two (11.8\%) cases an associated cardiac structural abnormality was diagnosed. The remaining pregnancies developed uneventfully and resulted in the delivery of a healthy infant.

Bradycardia was established as complete atrioventricular block in five cases (Fig. 1), as second degree 
Table 1 Clinical and ultrasound data of fetuses with ectopic beats

\begin{tabular}{|c|c|c|c|}
\hline $\begin{array}{l}\text { Case } \\
\text { No }\end{array}$ & $\begin{array}{l}\text { Gestational } \\
\text { age }(w k)\end{array}$ & Prenatal findings & Outcome \\
\hline $\begin{array}{l}1-15 \\
16\end{array}$ & $\begin{array}{l}23-41 \\
34\end{array}$ & $\begin{array}{l}\text { SVE ( } 14 \text { cases), VE ( } 1 \text { case) } \\
\text { SVE, severe IUGR, univentricular heart, } \\
\text { and coarctation of the aorta }\end{array}$ & $\begin{array}{l}\text { Term vaginal delivery, healthy infants } \\
\text { Stillbirth at } 34 \text { weeks, cardiac pathology } \\
\text { confirmed }\end{array}$ \\
\hline 17 & 36 & $\begin{array}{l}\text { SVE, obstructive foramen ovale, gross } \\
\text { right heart dilatation }\end{array}$ & $\begin{array}{l}\text { Term vaginal delivery; SVE after birth; } \\
\text { at } 6 \text { months has normal heart size and thythm }\end{array}$ \\
\hline
\end{tabular}

SVE, supraventricular ectopics; VE, ventricular ectopics; IUGR, intrauterine growth retardation.

Table 2 Clinical and ultrasound data of fetuses with bradycardia

\begin{tabular}{|c|c|c|c|}
\hline $\begin{array}{l}\text { Case } \\
\text { No }\end{array}$ & $\begin{array}{l}\text { Gestational } \\
\text { age }(w k)\end{array}$ & Prenatal findings & Outcome \\
\hline 18 & 21 & $\begin{array}{l}\text { Gross ascites, hydrothorax, CHB, isomeric } \\
\text { atria, absent right AV connection, great } \\
\text { arterial connections not clearly identified }\end{array}$ & $\begin{array}{l}\text { Pregnancy terminated at } 21 \text { weeks; ascites } \\
\text { hydrothorax, left atrial isomerism, } \\
\text { univentricular AV connection (single LV), } \\
\text { concordant arterial connections, } \\
\text { sub-pulmonary stenosis, asplenia, rocker } \\
\text { bottom feet }\end{array}$ \\
\hline 20 & $28+$ & $\begin{array}{l}\text { IUGR, irregular bradycardia, complete } \\
\text { AVSD }\end{array}$ & $\begin{array}{l}\text { Term vaginal delivery; complete AVSD + } \\
\text { wandering pacemaker; alive and well }\end{array}$ \\
\hline 21 & 29 & $\begin{array}{l}\text { CHB, structurally normal heart, maternal } \\
\text { collagenosis }\end{array}$ & $\begin{array}{l}\text { Caesarean section at term; CHB; clinically } \\
\text { well }\end{array}$ \\
\hline 22 & 29 & $\begin{array}{l}\text { Polyhydramnios, ascites, CHB, PE, } \\
\text { isomeric atria, complete AVSD, TOF, } \\
\text { gross ventricular hypertrophy }\end{array}$ & $\begin{array}{l}\text { Stillborn at } 31 \text { weeks; ascites; left atrial } \\
\text { isomerism; univentricular left AV } \\
\text { connection with straddling AV value; TOF; } \\
\text { right aortic arch with aberrant left } \\
\text { subclavian artery; asplenia }\end{array}$ \\
\hline 23 & 32 & $\begin{array}{l}\text { CHB, structurally normal heart, maternal } \\
\text { collagenosis }\end{array}$ & $\begin{array}{l}\text { Term vaginal delivery; } \mathrm{CHB} \text {; clinically } \\
\text { well }\end{array}$ \\
\hline 24 & 34 & $\begin{array}{l}\text { Mild sinus bradycardia, structurally normal } \\
\text { heart }\end{array}$ & $\begin{array}{l}\text { Term vaginal delivery; normal structure } \\
\text { and rhythm of heart }\end{array}$ \\
\hline 25 & 35 & $\begin{array}{l}\text { Polyhydraminios, second degree AV block, } \\
\text { VSD, great vessels not visualised }\end{array}$ & $\begin{array}{l}\text { Caesarean section at } 38 \text { weeks; second degree } \\
\text { AV block; died } 12 \text { h after birth, TOF, } \\
\text { trisomy } 18\end{array}$ \\
\hline
\end{tabular}

CHB, complete heart block; AV, atrioventricular; LV, left ventricle; AVSD, atrioventricular septal defect; PE, pericardial effusion; TOF, tetralogy of Fallot; VSD, ventricular septal defect; IUGR, intrauterine growth retardation.

Table 3 Clinical and ultrasound data of fetuses with tachycardia

\begin{tabular}{|c|c|c|c|}
\hline $\begin{array}{l}\text { Case } \\
\text { No }\end{array}$ & $\begin{array}{l}\text { Gestational } \\
\text { age (wk) }\end{array}$ & Antenatal findings & Outcome \\
\hline 26 & 25 & $\begin{array}{l}\text { Polyhydramnios; fetal hydrops; atrial } \\
\text { flutter with predominantly } 2: 1 \text { conduction; } \\
\text { structurally normal heart; maternal } \\
\text { intravenous administration of digitalis, } \\
\text { procainamide, and verapamil had no effect }\end{array}$ & $\begin{array}{l}\text { Stillbirth at } 26 \text { weeks; fetal hydrops; } \\
\text { structurally normal heart; block dissection } \\
\text { of SA node showed no clear abnormality }\end{array}$ \\
\hline 27 & 26 & $\begin{array}{l}\text { PSVT + multiple SVE; structurally normal } \\
\text { heart; spontaneous resolution of } \\
\text { arrhythmia at } 32 \text { weeks }\end{array}$ & $\begin{array}{l}\text { Term vaginal delivery; structurally normal } \\
\text { heart }\end{array}$ \\
\hline 28 & 31 & $\begin{array}{l}\text { SVT; structurally normal heart; mild PE; } \\
\text { maternal administration of digitalis had } \\
\text { no effect }\end{array}$ & $\begin{array}{l}\text { Caesarean section at } 36 \text { weeks; structurally } \\
\text { normal heart; control of arrhythmia with } \\
\text { digitalis; alive and well at } 1 \text { year }\end{array}$ \\
\hline 29 & 34 & $\begin{array}{l}\text { Maternal diabetes; atrial flutter with } \\
\text { variable conduction and periods of } \\
\text { NSR; structurally normal heart; maternal } \\
\text { administration of digitalis had no effect; } \\
\text { right heart dilatation and PE at } 38 \text { weeks }\end{array}$ & $\begin{array}{l}\text { Caesarean section at } 38 \text { weeks; structurally } \\
\text { normal heart; control of arrhythmia with } \\
\text { digitalis }\end{array}$ \\
\hline 30 & 36 & $\begin{array}{l}\text { Atrial flutter with variable AV conduction; } \\
\text { mild PE; structurally normal heart }\end{array}$ & $\begin{array}{l}\text { Caesarean section at } 36 \text { weeks; structurally } \\
\text { normal heart; control of dysrhythmia with } \\
\text { digitalis; alive and well at } 1 \text { year }\end{array}$ \\
\hline
\end{tabular}

PSVT, paroxysmal supraventricular tachycardia; SVE, supraventricular ectopics; SA, sinoatrial node; PE, pericardial effusion; NSR, normal sinus rhythm; AV, atrioventricular; SVT, supraventricular tachycardia. 

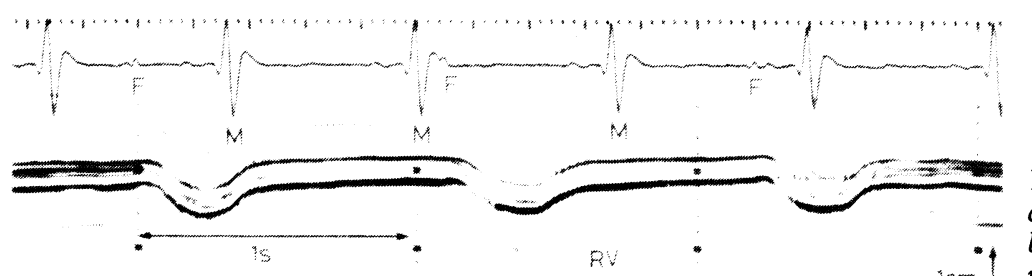

Fig. $1 M$ mode echocardiogram from case 21 showing complete congenital heart block. $F$, fetal $Q R S$ complex; $M$,

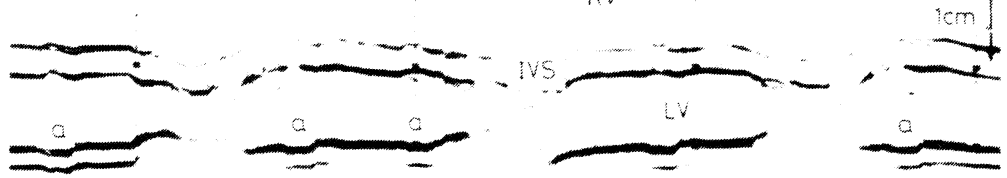
maternal $Q R S$ complex; $R V$, right ventricle; IVS, interventricular septum; $L V$, left ventricle; $a$, reflects independent atrial contraction on chordae tendinae of mitral valve.

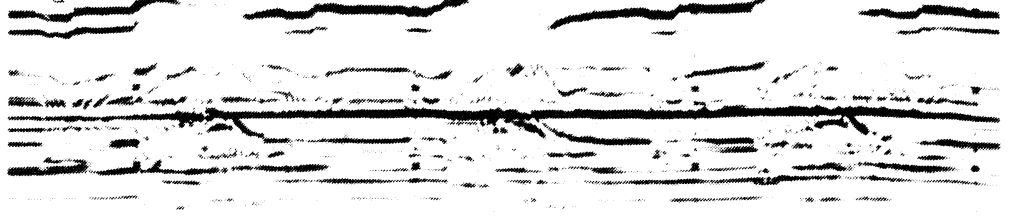

atrioventricular block in one case, was uncertain in one case, and probable mild sinus bradycardia in the remaining patient. In four (50\%) patients bradycardia was associated with a structural cardiac anomaly. Tachycardia was assessed as paroxysmal supraventricular tachycardia with spontaneous resolution in the 32nd week of pregnancy in one case, atrial flutter with variable atrioventricular conduction in three cases, and atrial flutter with variable atrioventricular conduction and short bursts of normal sinus rhythm in the remaining case. One patient (case 29) had a normal heart rate as shown on the cardiotocogram but was shown to have atrial flutter with variable atrioventricular conduction on $\mathbf{M}$ mode echocardiography (Fig. 2). In three cases maternal administration of $0.75 \mathrm{mg}$ digitalis daily failed to cardiovert the tachyarrhythmia.

\section{Discussion}

Disturbances of cardiac rate and rhythm in the fetus are usually discovered on auscultation during routine prenatal care. The fetal cardiotocogram accurately reflects rate and rhythm in the normal ranges $(120$ 160 beats/min) but may be inaccurate during tachyarrhythmia, as seen in case 29.6 The fetal transabdominal electrocardiogram monitors ventricular depolarisation but not usually atrial depolarisation and therefore has a limited function in the accurate determination of fetal arrhythmia. Combined cross sectional and $M$ mode echocardiography provides the most useful means of diagnosing abnormalities of cardiac rhythm and function in isolation, or in combination with structural heart disease. Pulsed Doppler assessment of blood flow in the descending aorta provides addi-

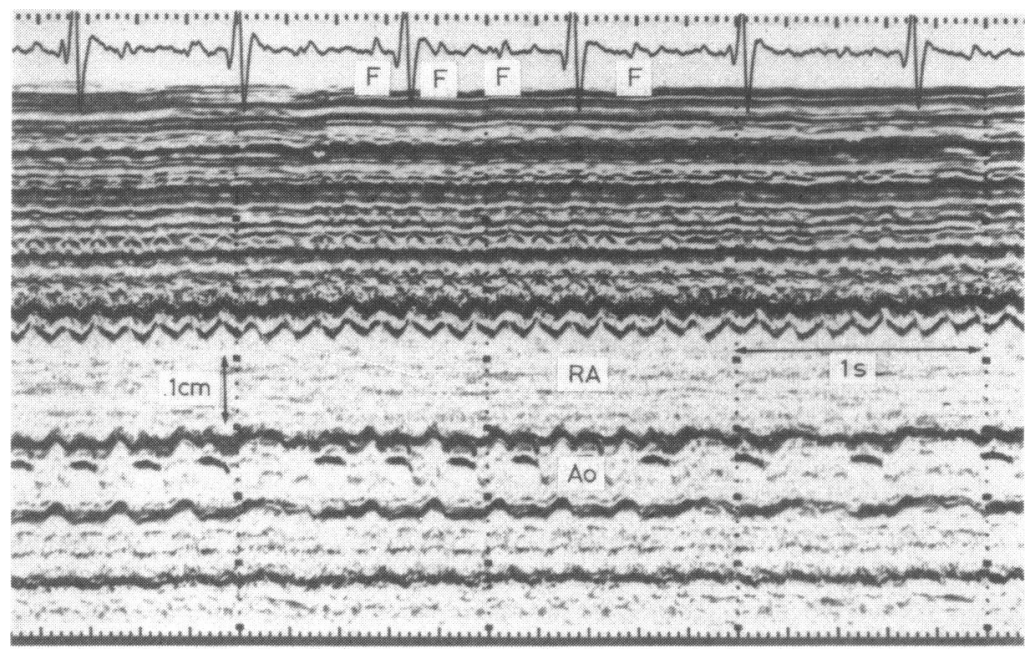

Fig. $2 M$ mode echocardiogram from case 29 showing atrial flutter with variable atrioventricular contraction as reflected by irregular opening of the aortic (Ao) valve. $F$, fetal $Q R S$ complex; $R A$, right atrium. 


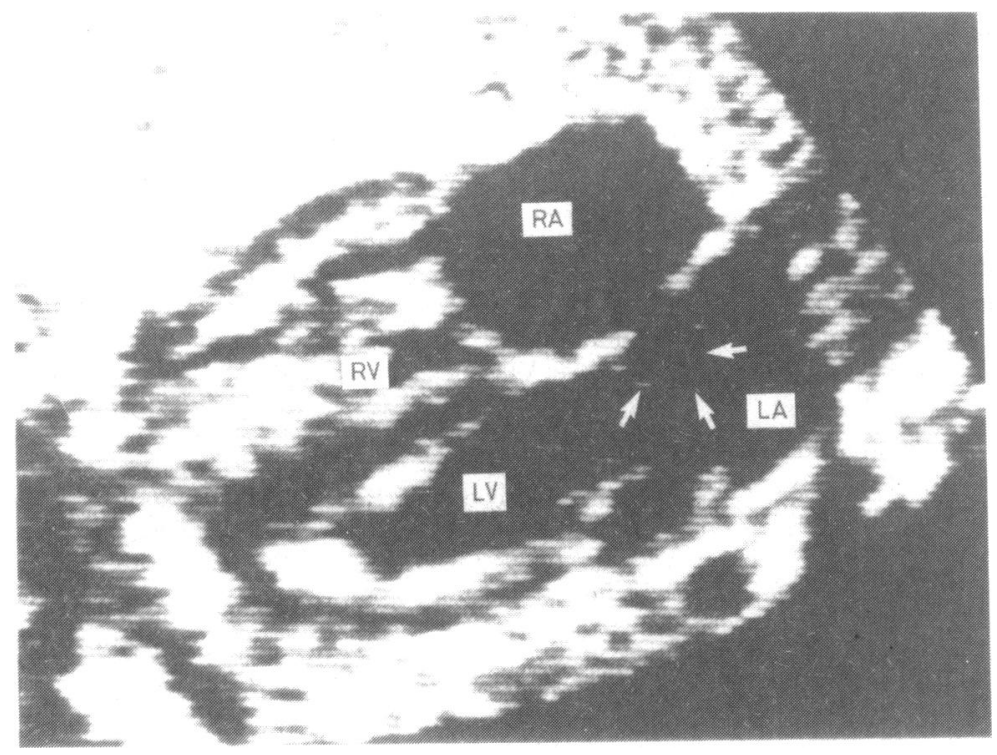

Fig. 3 Four chamber view from case 17 showing obstructive structure (arrows) at level of foramen ovale. In real time images the right atrium $(R A)$ and right ventricle $(R V)$ were grossly dilated and the interventricular septum moved paradoxically. $L A$, left atrium; $L V$, left ventricle.

tional information on cardiac function since it is well correlated with total cardiac output. ${ }^{10}$

In a prospective study of fetal heart rate and rhythm Southall et al.$^{11}$ found an incidence of $1.2 \%$ of premature beats, which was similar to that $(0.8 \%)$ in healthy neonates. ${ }^{12}$ These ectopic beats were considered benign and to be associated with a good prognosis. In our series, however, two (11.8\%) cases with ectopic beats had associated structural abnormalities (Fig. 3) resulting in fetal death in one. These instances emphasise the need for detailed structural analysis of the heart in the presence of arrhythmias. Regular screening of fetuses without structural defect is recommended as triggering of a sustained arrhythmia may occur from one of these ectopic beats. ${ }^{13}$ Vaginal delivery should be possible in cases in which isolated ectopic beats are found.

In our study bradycardia was associated with a $50 \%$ mortality rate. One fetus (case 19) with no structural abnormality and complete congenital heart block associated with maternal Waldenström's disease died two days postpartum from intractable cardiac failure. The remaining three fetuses had associated structural heart disease and congestive cardiac failure and died in utero or shortly after birth.

It is clear from these data that fetuses with structural heart disease or evidence of congestive cardiac failure in the presence of sustained arrhythmia, or both, have a more ominous prognosis. Until recently caesarean section has been the method of delivery in cases of fetal congenital heart block without cardiac compromise. Although vaginal delivery was successful in case 23 , an emergency caesarean section had to be carried out in case 21 as fetal scalp pH dropped to 7.07 , whereas baseline atrial heart rate remained at 150 beats/min without appreciable changes relative to uterine contractions. Furthermore, elective caesarean section allows optimal timing of the delivery with respect to immediate postpartum care by the neonatologist and paediatric cardiologist. Termination of pregnancy may be recommended (case 18) in cases in which complex congenital heart disease, cardiac failure, and arrhythmia are diagnosed early in pregnancy.

The previable fetus with severe congestive cardiac failure due to tachyarrhythmia presents a serious therapeutic problem, and fetal death may occur in such cases. There have been several reports of successful fetal cardioversion by administration of various drugs to the mother,,$^{14-17}$ digitalis being the mostly commonly used as it readily crosses the placenta. ${ }^{18}$ Our experiences contrast directly with those of the above authors, as the four fetuses treated by us failed to respond to treatment. Case 26 presented at $>25$ weeks with gross ascites and maternal polyhydramnios and a heart rate of about 240 beats/ $\mathrm{min}$. Over eight days intravenous administration of digitalis, procainamide, and verapamil to the mother failed to convert the tachycardia, and the fetus died at $>26$ weeks' gestation. The digitalis dosage was 0.75 $\mathrm{mg} /$ day for five days; on the sixth day $1 \mathrm{~g}$ procainamide was given over one hour with a maintenance dose of $4 \mathrm{~g} / 24$ hours and digitalis was reduced to $0.5 \mathrm{mg}$; and on the eighth day $10 \mathrm{mg}$ verapamil given over one hour was added because of the worsening fetal condition. The degree of polyhydramnios 
and ascites may have played some part in the availability of these drugs to the fetus, but a report by Klein $e t$ al. ${ }^{19}$ describing failure of treatment before the development of hydrops may indicate a more complicated mechanism in some cases. The transmission of verapamil across the placenta is variable, ${ }^{20}$ but verapamil was selected in this case in which the arrhythmia proved refractory to digitalis and procainamide.

Case 29 showed periods of normal sinus rhythm, which were initially attributed to successful treatment with digitalis. We subsequently learnt that the maternal serum digitalis concentrations were $0.5 \mathrm{ng} / \mathrm{ml}$ at the first recording of normal sinus rhythm. Despite the periods of normal sinus rhythm this fetus developed enlargement of the right heart and mild pericardial effusion, resulting in delivery by caesarean section at $>38$ weeks' gestation. Careful monitoring by all methods is mandatory in all fetuses with tachyarrhythmia as this is a high risk group. Transplacental treatment must be attempted in the hope of achieving cardioversion and preventing congestive cardiac failure in the previable fetus. In the viable fetus refractory arrhythmias should be further treated by elective caesarean section and pharmacological or electrical cardioversion immediately after birth.

We thank all our colleagues for referring their patients to this ultrasound unit. We particularly thank Professor A E Becker (University of Amsterdam) and Dr C E Essed (Erasmus University, Rotterdam) for their pathology findings. We also thank Hewlett-Packard for donating a 77020A ultrasound imaging system for part of this work, and the Department of Clinical Genetics, Erasmus University, Rotterdam, for providing a Diasonics Cardiovue 100 for our fetal structural abnormality screening programme.

\section{References}

1 Lange LW, Sahn DJ, Allen HD, Goldberg SJ, Anderson C, Giles, H. Qualitative real-time cross-sectional echocardiographic imaging of the human fetus during the second half of pregnancy. Circulation 1980; 62: 799-806.

2 Sahn DJ, Lange LW, Allen HD, et al. Quantitative realtime cross-sectional echocardiography in the developing normal human fetus and newborn. Circulation 1980; 62: 588-97.

3 Allan LD, Tynan M, Campbell S, Anderson RH. Normal fetal cardiac anatomy-a basis for the echocardiographic detection of abnormalities. Prenatal Diagn 1981; 1: 131-9.

4 Stewart PA, Wladimiroff JW, Essed CE. Prenatal ultrasound diagnosis of congenital heart disease associated with intrauterine growth retardation. A report of 2 cases. Prenatal Diagn 1983 (in press).

5 Kleinman CS, Donnerstein RL, DeVore GR, et al. Fetal echocardiography for evaluation of in utero congestive cardiac failure; a technique for study of nonimmune fetal hydrops. N Engl f Med 1982; 306: 568-75.

6 Kleinman CS, Donnerstein RL, Jaffe CC, et al. Fetal echocardiography. A tool for evaluation of in utero cardiac arrhythmias and monitoring of in utero therapy: analysis of 71 patients. Am $\mathcal{F}$ Cardiol 1983; 51: 237-43.

7 Wladimiroff JW, McGhie JS, Hovestreydt-Snijder RP, Tasseron EWK. M-mode and pulsed Doppler ultrasound assessment of severe fetal bradycardia. A case report. Br $\mathcal{F}$ Obstet Gynaecol 1981; 88: 1246-8.

8 Wladimiroff JW, Struyk P, Stewart PA, Clusters P, De Villeneuve VH. Fetal cardiovascular dynamics during cardiac dysrhythmia: case report. Br $\mathcal{F}$ Obstet Gynaecol 1983; 90: 573-7.

9 Eik-Nes SH, Brubakk AO, Ulstein M. Measurement of human fetal blood flow. Br Med F 1980; 280: 283-5.

10 Tonge HM, Struyk PC, Custers P, Wladimiroff JW. Vascular dynamics in the descending aorta of the human fetus in normal late pregnancy. Early Hum Dev 1983 (in press).

11 Southall DP, Richards J, Hardwick R, et al. Prospective study of fetal heart rate and rhythm patterns. Arch Dis Child 1980; 55: 506-11.

12 Southall DP, Johnson AM, Shinebourne EA, Johnston PGB, Vulliamy DG. Frequency and outcome of disorders of cardiac rhythm and conduction in a population of newborn infants. Pediatrics 1981; 68: 58-66.

13 Gillette, PC. The mechanisms of supraventricular tachycardia in children. Circulation 1976; 54: 133-9.

14 Lingman G, Orhlander S, Ohlin O. Intrauterine digoxin treatment of fetal paroxysmal tachycardia. Case report. Br $\mathcal{F}$ Obstet Gynaecol 1980; 87: 340-2.

15 Kerenyi TD, Gleicher N, Meller J, et al. Transplacental cardioversion of intrauterine supraventricular tachycardia with digitalis. Lancet 1980; ii: 393-5.

16 Harrigan JT, Kangos JJ, Sikka A, et al. Successful treatment of fetal congestive heart failure secondary to tachycardia. $N$ Engl f Med 1981; 304: 1527-9.

17 Dumesic DA, Silverman NH, Tobias S, Golbus MS. Transplacental cardioversion of fetal supraventricular tachycardia with procainamide. $N$ Engl $\mathcal{F}$ Med 1982; 307: 1128-31.

18 Rogers MC, Willerson JT, Goldblatt A, Smith TW. Serum digoxin concentrations in the human fetus, neonate and infant. N Engl $\mathcal{F}$ Med 1972; 287: 1010-3.

19 Klein AM, Holzman IR, Austin EM. Fetal tachycardia prior to the development of hydrops-Attempted pharmacologic cardioversion. Case report. Am $\mathcal{F}$ Obstet Gynecol 1979; 134: 347-8.

20 Strigl R, Gastroph G, Hege HG, Döring P, Mehring W. Nachweis von Verapamil im mütterlichen und fetalen Blut des Menschen. Geburtsh u Frauenheilk 1980; 40: 496-9.

Requests for reprints to Professor J W Wladimiroff, Department of Obstetrics and Gynaecology, Academic Hospital Rotterdam-Dijkzigt, Erasmus University Rotterdam, Dr Molewaterplein 40, 3015 GD Rotterdam, The Netherlands. 